\title{
Investigation of heavy metal accumulation in mung bean through inductively coupled plasma optical emission spectroscopy
}

\author{
Azene Tesfaye $^{1 *} \quad$ Tadesse Feleke ${ }^{2}$ \\ ${ }^{1}$ Arba Minch University, Arba minch Ethiopia \\ ${ }^{2}$ Debre Birhan University, Debre Birhan, Ethiopia \\ *correspondence azet567@gmmail.com
}

\begin{abstract}
Vigina radiata (Mung bean) is an important legume species belongs to the family Fabaceae, cultivated in varies region of Ethiopia for its nutritional values. The nutritional composition of the crop affected by different biotic and environmental stress which depends on growth environment. The aim of the present study was to determine the concentrations of selected heavy metals $(\mathrm{Pb}, \mathrm{Cu}$ and $\mathrm{Cr}$ ) in seed of mung bean collected from Shewarobit, Northcentral Ethiopia using inductively coupled plasma optical emission spectroscopy (ICP-OES). Acid digestion with $\mathrm{HCl}, \mathrm{HNO}_{3}$ and $\mathrm{HClO}_{4}$ for $1 \mathrm{hr}$ at temperature of $90^{\circ} \mathrm{C}$ to $95^{\circ} \mathrm{C}$ by hot plate digester. The level of the heavy metals in the samples were $2.51 \mathrm{mg} / \mathrm{L}, \mathrm{Pb} ; 6.53 \mathrm{mg} / \mathrm{L}, \mathrm{Cu}$; and $0.38 \mathrm{mg} / \mathrm{L}, \mathrm{Cr}$ respectively. The concentration of copper $(\mathrm{Cu})$ in the seed of mung bean was higher than the other target metals ( $\mathrm{Pb}$ and $\mathrm{Cr}$ ) whereas, $\mathrm{Cr}$ occurred in least concentration. The overall accuracy of the method obtained from spiking experiment (recovery) was within the range 80 to $120 \%$, which accounts 115.75\%, 97.5\%, 101.17\% for $\mathrm{Pb} \mathrm{Cr}$ and $\mathrm{Cu}$ respectively. Notably, these results indicating the reliability and applicability of the procedure for extraction of studied metals. The concentration of heavy metals in edible seed of mungbean is low as compared to WHO/FAO recommendation and absolutely safe for consumption in the study area. Thus, producer should follow similar agroecological managements of the crop production to maintain heavy metal concentration of such in the crop.
\end{abstract}

Key words: Heavy metals, ICP-OES, Mungbean, Seed, Shewarobit

\section{Introduction}

Mung bean is a leguminous annually pulse crop which mostly grows in low land areas of Ethiopia. Due to its nature of water logging sensitivity, most of its productions based on irrigation $\mathrm{n}$ under irrigation. Mung bean widely cultivated for its nutritional values. it used as sources of proteins, 
essential amino acids, vitamins and minerals. They also contain thiamin, iron, magnesium and other nutrients and is a good source of foliate

Different research anticipated Heavy metals are also essential for the normal growth and metabolism of plants and play very important role in the biosynthesis of some enzymes and growth hormones (Jia, Wang et al. 2010). However, the normal growth and metabolism of many plants/crops were reported to be affected adversely by excess supply of heavy metals (Sharma and Agrawal 2005). The accumulation of heavy metals in mungbean grown on metalliferous mine spoil (Samantaray and Das 1997).

Heavy metals occur naturally in the Earth's crust (Chang, Yin et al. 2019) and are extensively mined in various parts of the world. This practice has hugely contributed to the uncontrollable anthropic inputs into the environment. These heavy metals have a very long half-life, and therefore persist in the environment for extended periods, because they cannot be degraded (Jan, Azam et al. 2015). Therefore, they can accumulate and exert toxic effects on microorganisms, plants, animals, and humans. Heavy metals have become a major environmental issue, and if the current environmental contamination persists, then heavy metal pollution will also be a great concern for the future(Ayangbenro and Babalola 2017). Heavy metals pollution is widely spread, due to rapid industrialization and current agricultural practices(Chukwulobe and Saeed 2014). These pollutants persist in the environment for a longer period, as they are not easily degraded by soil

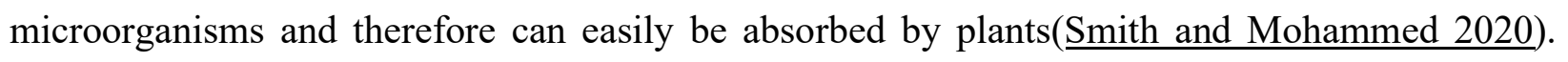
Heavy metals that have been absorbed by the plants results in growth inhibition, increasing senescence which leads to decreasing crop yield (Sharma and Agrawal 2005). Moreover, heavy metals can be accumulated in the crops and affect human health upon consumption (Proshad, Kormoker et al. 2019), metals can be found in soils because they are present in insecticides, fungicides, sludge and commercial fertilizers (World Health 1996, Mendoza, Llopis et al. 2006, Jia, Wang et al. 2010). Metals within the soil solution are the only soil fraction directly available for plant uptake (Tegegne 2015, Muzeyen 2019). Thus, factors which affect the concentration and speciation of metals in the soil solution will affect the bioavailability of metals to plants (Adelekan and Abegunde 2011). 
The presence of heavy metals in mung bean in higher concentration causes for the fall of seed germination. The effects of metals toxicity on the germination of mung bean seeds were used as a model in this study, since seeds were well protected against various stress which soon after imbibitions and subsequent vegetative developmental process, become stress sensitive in general (Sethy and Ghosh 2013). Heavy metal contamination of soil vial sewage influx, contaminated ground waters etc. could induce serious problems to soil, cropping, vegetation and in turn human health. Heavy metal accumulation by plant tissues, its presence in the soil persistently or its presence in ground waters was not a healthy sign for the environment. If the metals are ingested beyond the permitted concentration, they could cause serious health disorders (Tegegne 2015).

Heavy metal stress, which directly affects food crops, has detrimental impacts on food access (amount of food) and food utilization (safety and nutrition). The impacts of heavy metal stress on food safety enjoy much of the attention, but very little is reported on the impacts of heavy metals on food access (crop yields from fields) and nutrition (impact on important dietary nutrients). Mung bean used as food for human beings and there might be large concentration of heavy metals accumulated in the human body(Manea, Ienciu et al. 2020). Studies have shown that soils of refuse dumpsite contain different kinds and concentrations of heavy metals (Smith and Mohammed 2020). The rise in population in Shewarobit town has increased the number of dumpsite due to poor waste management schemes. It was a common practice to burn dumpsite wastes; this burning gets rid of organic matter and became ashes which were richer in metal contents (Sharma and Agrawal 2005, Onder, Dursun et al. 2007). These ashes were either dissolved in rain water and leached into the soil contaminating the underground water, or washed away by runoff into streams and rivers, thereby contaminating the environment. In addition, the farmer and producers of mung bean applied different insecticides fertilizers and herbicides which can pollute the soil on which mung bean grows and many causes for the uptake of heavy metals by mungbean. In addition to this, farmers use flowing river water for irrigation to grow mungbean but different waste materials including by products of metal work and wood work were wasted to the river which may cause in the increment of heavy metals concentration in mung bean. To this end, the present study aimed to determine the concentrations of selected heavy metals in the seed of mung bean collected from shawarobit, Northcenteral Ethiopia. 


\section{Methods and Materials}

\section{Description of study area and plant material}

Healthy mature dried seed of mung bean were collected from Agricultural lands located in Shewarobit Administration office, Amhara regional state, Northcentral Ethiopia. Shewarobit town administration which is located $220 \mathrm{~km}$ north of Addis Ababa. Mung bean is highly producing in the town. The seed was sieved and grounded to fine powder using porcelain mortar and pestle store in plastic bag (zip lock) at room temperature and analysed for selected heavy metals including lead $(\mathrm{Pb})$, copper $(\mathrm{Cu})$ and chromium $(\mathrm{Cr})$ using ICP-OES Horticoop Ethiopia PLC Soil and Water Analysis Laboratory, Debre Zeit, Ethiopia.

\section{Experimental procedures}

Prior to the actual experiment sample preparation was carried out following the standard procedures. $5 \mathrm{~g}$ of mungbean flavour were weighed and transferred to a clean crucible, which was labelled according to the sample and dry ashing process would be carried out in muffle furnace by stepwise increase of the temperature up to $5500 \mathrm{C}$ and left to ash at this temperature for $6 \mathrm{hrs}$. The sample was removed from the furnace and allowed to cool. The ash was wetted with water and 2.5 $\mathrm{mL}$ of concentrated HNO3 was added. The beaker with a glass cover still intact then placed on a warm hot plate to commence wet ashing. The digestion had been performed at a temperature of 90 to 95 0C for $1 \mathrm{hr}$. The ash had been dissolved in $5 \mathrm{~mL}$ of $9.25 \% \mathrm{HCl}$ and digested again on a hot plate until the white fumes ceased to exist and sample reached to $2 \mathrm{~mL}$. Then $2 \mathrm{~mL} 70 \% \mathrm{HClO} 4$ was added to the cooled solution and heating resumed until clear solution was appeared. As all $\mathrm{HNO} 3$ eventually evaporated, fumes of $\mathrm{HClO} 4$ appeared; heating maintained until ashing was completed. The $\mathrm{HClO} 4$ then removed by evaporation. The residue had been treated with $5 \mathrm{~mL}$ of concentrated $\mathrm{HCl}$ and the acid was refluxed in the beaker; an equal volume of water was then added with subsequent evaporation to dryness. This refluxing process with concentrated $\mathrm{HCl}$ followed by evaporation to dryness repeated. Finally, $1.0 \mathrm{~mL}$ concentrated $\mathrm{HCl}$ added and the mixture was warmed briefly; then $15 \mathrm{~mL}$ of water was added and the solution has been heated for about $15 \mathrm{~min}$. After it was cooled $20 \mathrm{~mL}$ of distilled water were added and filtered using whatman filter. The filtered sample was diluted up to the mark of $50 \mathrm{~mL}$ standard volumetric flask, and transferred to a $50 \mathrm{~mL}$ polyethylene storage bottle until analysis. A sample was prepared 
identically in triplicate. ICP-OES measurement was then made for each individual element along with the appropriate standard solution. The sample was digested in triplicate (Onder, Dursun et al. 2007, Tegegne 2015, Muzeyen 2019)

\section{Soil pH and Electrical conductivity}

The soil sample which mung bean grows was collected using polyethylene tube in depth of around $40 \mathrm{~cm}$ following scientific procedures of soil sampling. $\mathrm{pH}$ and electric conductivity of the soil was evaluated based on the method described (Adelekan and Abegunde 2011).

\section{Experiment Protocols and calibration}

All standard stock solutions were $1000 \mathrm{ppm}$ in nitric acid which was imported from inorganic ventures by dilution with $0.5 \%$ nitric acid. All standard solutions were prepared in $50 \mathrm{~mL}$ graduated tube by filling to their mark volume. A mixture of working standard solution of $\mathrm{Cu}, \mathrm{Pb}$ and $\mathrm{Cr}$ was prepared from the stock solutions containing $1000 \mathrm{ppm}$. Calibration curves were done for each element (Tegegne 2015).

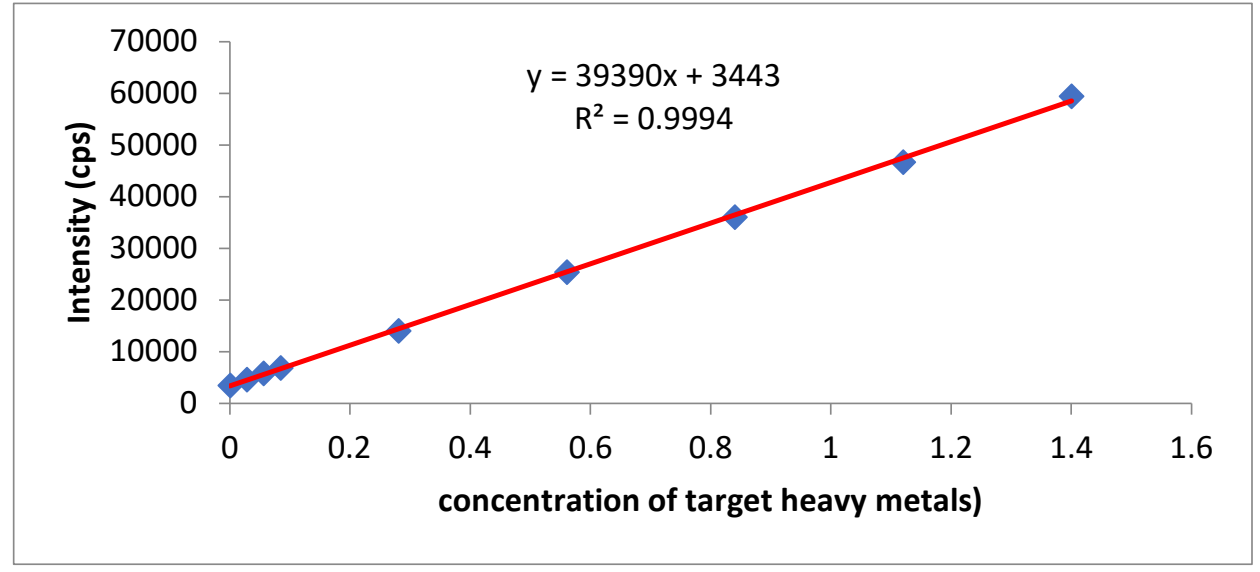

Figure 1:schematic representation of calibration curves for target heavy metals 
Table 1: Instrumental operating condition for determination of heavy metals using ICP-OES from mungbean seeds

\begin{tabular}{|c|c|c|c|c|c|c|c|c|}
\hline 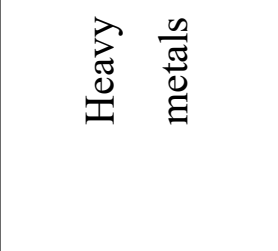 & 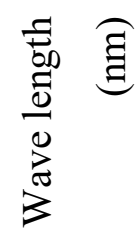 & 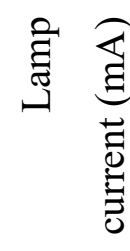 & 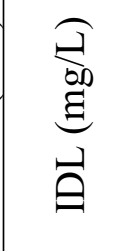 & 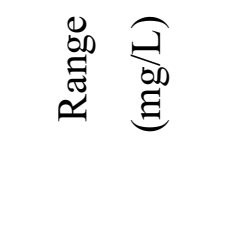 & 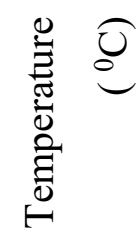 & 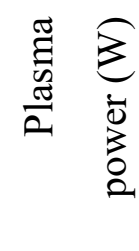 & 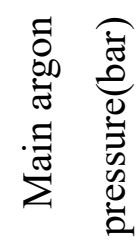 & 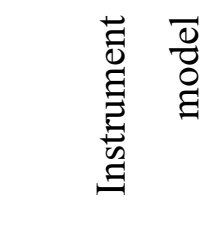 \\
\hline Lead $(\mathrm{Pb})$ & $\begin{array}{l}220.35 \\
3\end{array}$ & 607 & 0.0007 & $0.0007-1.68$ & \multirow{3}{*}{51.53} & \multirow{3}{*}{1400} & \multirow{3}{*}{6.75} & \multirow[t]{3}{*}{$\begin{array}{l}\text { ARCOS } \\
\text { FHS12 }\end{array}$} \\
\hline Copper $(\mathrm{Cu})$ & $\begin{array}{l}324.75 \\
4\end{array}$ & 607 & 0.0025 & $0.0025-3.36$ & & & & \\
\hline Chromium $(\mathrm{Cr})$ & $\begin{array}{l}267.71 \\
6\end{array}$ & 607 & 0.001 & $0.001-1.4$ & & & & \\
\hline
\end{tabular}

Table 2:correlation coefficient of the calibration curves for the determination of metals in mungbean using ICP-OES

\begin{tabular}{lcc}
\hline Metals & $\begin{array}{c}\text { Concentration of } \\
\text { standards }(\mathbf{m g} / \mathbf{L})\end{array}$ & $\begin{array}{c}\text { Correlation coefficient }(\mathbf{R}) \text { of Calibration } \\
\text { curves }\end{array}$ \\
\hline Lead $(\mathrm{Pb})$ & $0,0.028,0.056,0.084,0.28$, & \\
& $0.56,0.84,1.12,1.4$. & 0.999757 \\
Copper $(\mathrm{Cu})$ & $0,0.2,0.4,0.8,1.2,1.6,2.0$, & \\
& $2.4,2.8$. & 0.999377 \\
Chromium(Cr) & $0,0.028,0.056,0.084,0.28$, \\
& $0.56,0.84,1.12,1.4$. & \\
&
\end{tabular}




\section{Results and Discussion}

\section{Soil pH and Electric conductivity}

As the experimental analyses showed that the $\mathrm{pH}$ of the soil sample was $6.93 \pm 0.153$. The experimental analyses showed that the electrical conductivity of the soil sample was $181.33 \mu \mathrm{s} / \mathrm{cm}$ $\pm 2.52(0.18133 \mathrm{dS} / \mathrm{m} \pm 2.52)$. This confirmed that the soil sample was normal because its EC was $0.1811 \mathrm{dS} / \mathrm{m}$ and which was in the range of normal electrical conductivity $(<0.8 \mathrm{dS} / \mathrm{m})$.

\section{Concentration of heavy metals in Seed of Mung bean}

The concentration of lead in mungbean was $2.51 \mathrm{mg} / \mathrm{L} \pm 0.236$. The permissible limit according to WHO standard (1996) is $2 \mathrm{mg} / \mathrm{L} \pm 0.236$. In the sample the concentration of lead exceeded compared with lead standard ( $2 \mathrm{mg} / \mathrm{L})$. As the experimental analyses shown that in table 4 the concentration of copper in mungbean was $6.53 \mathrm{mg} / \mathrm{L} \pm 0.039$. The permissible limit according to WHO (1996) standard is $10 \mathrm{mg} / \mathrm{L} \pm 0.039$. The concentration of copper in the sample was lowered compared with copper standard $(10 \mathrm{mg} / \mathrm{L})$. As the experimental analyses shown in table 4 the concentration of chromium in mungbean seed was $0.38 \mathrm{mg} / \mathrm{L} \pm 0.085$. The permissible limit according to WHO (1996) standard is $1.3 \mathrm{mg} / \mathrm{L} \pm 0.085$. 


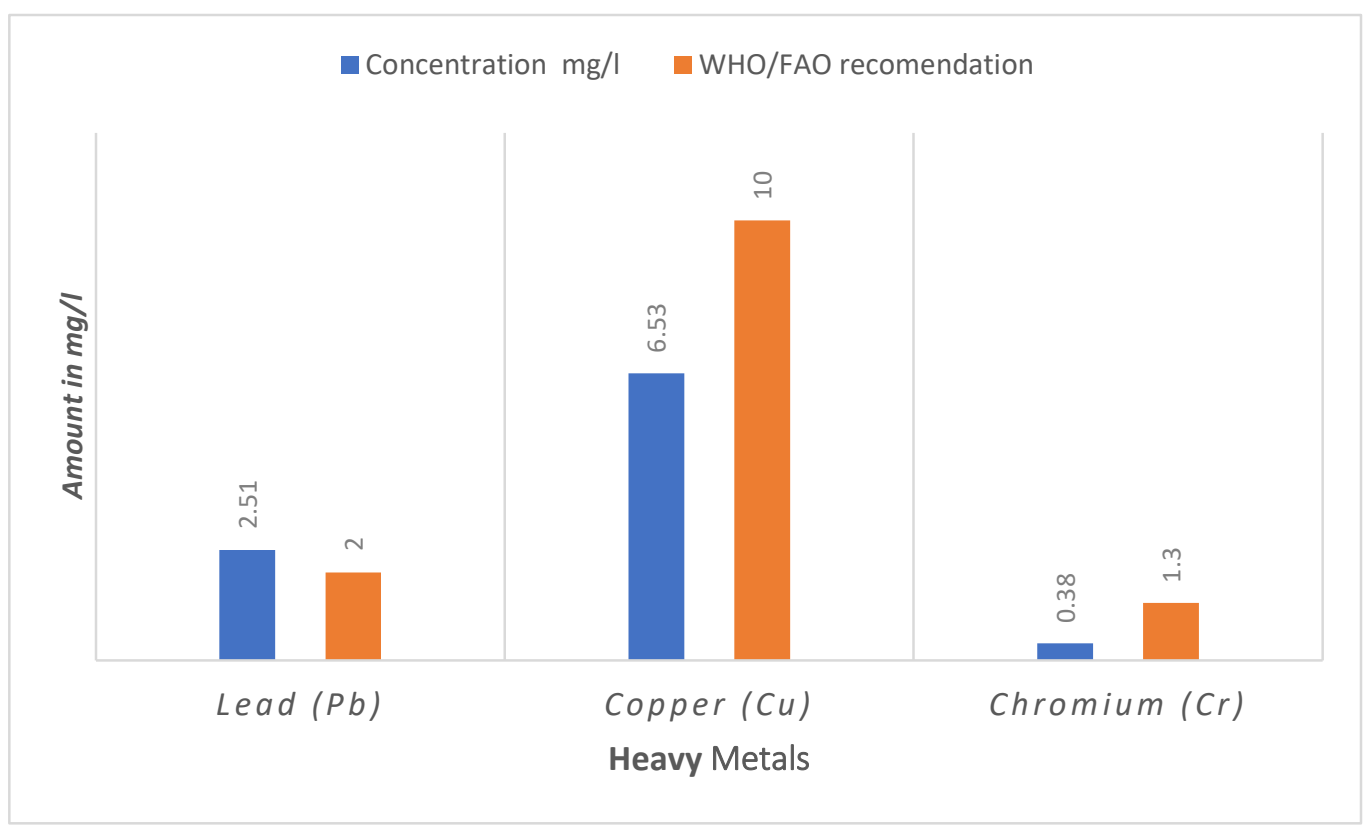

Figure 2: Concentrations of the heavy metals $(\mathrm{Pb}, \mathrm{Cu}$ and $\mathrm{Cr})$ as compared to with the recommended concentration by $\mathrm{WHO} / \mathrm{FAO}$ in mungbean

\section{Method Validation and Recovery Test}

Method validation is the way of testing a particular analytical method to check, if it is suitable for its intended purpose. The efficiency of the digestion procedure was checked by adding known concentration of each metal in a $5 \mathrm{~g}$ of sample. For recovery analysis a mixture of $4 \mathrm{mg} / \mathrm{L}$ of $\mathrm{Pb}$, $2 \mathrm{mg} / \mathrm{L}$ of $\mathrm{Cu}$ and $6 \mathrm{mg} / \mathrm{L} \mathrm{Cr}$ was spiked to all samples.

\section{Percentage recovery $=\frac{\text { Concentration in spikedsample }- \text { Concentration in unspikedsample }}{\text { Amount spiked }} \times 100$}

the percentage recoveries of $\mathrm{Cu}, \mathrm{Pb}$ and $\mathrm{Cr}$ values of the concentration of heavy metals obtained for this work, percentage recoveries of $\mathrm{Pb}, \mathrm{Cu}$ and $\mathrm{Cr}$ were $115.75,97.5$ and $101.17 \%$ respectively. These values were within the acceptable range of 80 to $120 \%$ expected for the elements indicating good accuracy for the analysis procedure (Duan, et al., 2003). These results therefore confirmed that the reliability of the method for the determination of the metals $(\mathrm{Pb}, \mathrm{Cu}$ and $\mathrm{Cr})$. 
Table 3: Percentage recovery of the sample

\begin{tabular}{llllll}
\hline Heavy metals & $\begin{array}{l}\text { Unpicked } \\
\text { amount } \\
(\mathrm{mg} / \mathrm{L})\end{array}$ & $\begin{array}{l}\text { Amount added } \\
\text { in }(\mathrm{mg} / \mathrm{L})\end{array}$ & $\begin{array}{l}\text { Amount } \\
\text { after spike } \\
(\mathrm{mg} / \mathrm{L})\end{array}$ & $\begin{array}{l}\text { Standard } \\
\text { deviation }\end{array}$ & $\begin{array}{l}\% \text { Recovery } \pm \\
\text { standard deviation }\end{array}$ \\
\hline Copper $(\mathrm{Cu})$ & 6.53 & 2 & 4.48 & 0.039 & $97.5 \pm 0.039$ \\
Lead $(\mathrm{Pb})$ & 2.51 & 4 & 7.14 & 0.236 & $115.75 \pm 0.236$ \\
Chromium $(\mathrm{Cr})$ & 0.38 & 6 & 6.45 & 0.085 & $101.17 \pm 0.085$ \\
\hline
\end{tabular}

As the experimental analysis signified that the mean was $0.085 \pm 0.036$ for lead, $1.581 \pm 0.122$ for copper and $0.269 \pm 0.15$ for chromium. As observed in table 7 the standard deviation of the blank of each metal was less than the least concentration of each metal $(\mathrm{Pb}: 0.036<2.24, \mathrm{Cu}: 0.122<$ 6.51 , and $\mathrm{Cr}: 0.15<0.28$ ). Therefore the concentration of the heavy metals in the blank was the least compared with their concentration in the sample. All the above informations had been confirmed that the method was more reliable for the determination of the heavy metals in the sample.

Table 4: Mean and standardvetion of heavy metals in mung bean

\begin{tabular}{lll}
\hline Metals & Mean & Mean $\pm \mathrm{SD}$ \\
\hline Lead $(\mathrm{Pb})$ & 0.085 & $0.085 \pm 0.036$ \\
Copper $(\mathrm{Cu})$ & 1.581 & $1.581 \pm 0.122$ \\
Chromium $(\mathrm{Cr})$ & 0.269 & $0.269 \pm 0.15$ \\
\hline
\end{tabular}

\section{Instrument calibration}

In table 3 the results of analyses of heavy metals by inductively coupled plasma optical emission spectrometer was shown. The concentrations of target analyte were measured in triplicate. Based on the quantified concentration of target analyte in mungbean seed, the concentration of $\mathrm{Cr}<\mathrm{Pb}<\mathrm{Cu}$. the concentrations of lead, copper and chromium in each trial agree with each other. The standard deviations for each metal were very low which indicates the precision is high. This confirmed that the precision is good because each measurement in each metal close to the average of the series. However, the precision in copper was highest compared with the precisions in lead and chromium. Therefore the measurement in copper was the most precise. 
Table 5:The concentration of $\mathrm{Cu}, \mathrm{Pb}$ and $\mathrm{Cr}$ in Mungbean determined by ICP-OES

\begin{tabular}{clll}
\hline Description & Pb $\mathbf{~ m g} / \mathbf{L}$ & $\mathbf{C u ~} \mathbf{~ m g} / \mathbf{L}$ & $\mathbf{C r ~ m g / L}$ \\
\hline Mean \pm SD & $2.51 \pm 0.236$ & $6.53 \pm 0.039$ & $0.38 \pm 0.085$ \\
& & & \\
\hline
\end{tabular}

\section{Method quantification limit (MDL)}

MDL is the lowest concentration of analyte that can be measured in sample matrix at an acceptable level of precision and accuracy; it is the same as the concentration which gives a signal ten times the standard deviation of blank. It is calculated as:

\section{Quantification limit $=10 \times$ Standard deviation of blank}

MDL is greater than the detection limit of the instrument, which confirmed that the method was available and the instrument better detected the concentration of the heavy metals in the sample. The MQL was the least which indicated that the accuracy is high. Therefore, the method (procedures) was more reliable.

Table 6:Detection and quantification limits of $\mathrm{Pb}, \mathrm{Cu}$ and $\mathrm{Cr}$ metals in mungbean.

\begin{tabular}{lll}
\hline Metals & MDL in $\mathrm{mg} / \mathrm{L} \pm \mathrm{SD}$ & MQL in $\mathrm{mg} / \mathrm{L} \pm \mathrm{SD}$ \\
\hline Lead $(\mathrm{Pb})$ & $0.108 \pm 0.036$ & $0.36 \pm 0.036$ \\
Copper $(\mathrm{Cu})$ & $0.366 \pm 0.122$ & $1.22 \pm 0.122$ \\
Chromium $(\mathrm{Cr})$ & $0.45 \pm 0.15$ & $1.5 \pm 0.15$ \\
\hline
\end{tabular}

\section{Conclusion}

In the study the metal content of mung bean which grew by irrigation had been investigated. The concentrations of the heavy metals $(\mathrm{Pb}, \mathrm{Cu}$ and $\mathrm{Cr})$ have been analyzed by inductively coupled plasma optical emission spectrometer (ICP-OES). The concentrations of copper and chromium investigated in this research were lower than the values reported by WHO. But the concentration of lead was higher than the values reported by WHO. The excess lead concentration in mung bean seed may result from house hold materials like cosmetics containers, fossil fuels, animal wastes and remains that entered to the irrigation water. Therefore, to use mung bean for a day to day consumption, it had to be taken care in cultivation, processing, transports and sells of mung bean to the consumer. 


\section{Acknowledgment}

The authors thankful for Debre Birhan university and Horticoop Ethiopia PLC Soil and Water Analysis Laboratory for their contribution during the research work.

\section{References}

Adelekan, B. A. and K. D. Abegunde (2011). "Heavy metals contamination of soil and groundwater at automobile mechanic villages in Ibadan, Nigeria." International journal of physical sciences 6(5): 1045-1058.

Ayangbenro, A. S. and O. O. Babalola (2017). "A new strategy for heavy metal polluted environments: a review of microbial biosorbents." International journal of environmental research and public health 14(1): 94.

Chang, C., R. Yin, H. Zhang and L. Yao (2019). "Bioaccumulation and Health Risk Assessment of Heavy Metals in the Soil-Rice System in a Typical Seleniferous Area in Central China." Environmental toxicology and chemistry 38(7): 1577-1584.

Chukwulobe, E. E. and M. D. Saeed (2014). "Assessment of some physicochemical properties and levels of $\mathrm{Pb}, \mathrm{Cu}$ and $\mathrm{Zn}$ in soils of selected dumpsites in Kano Metropolis, North-West, Nigeria." International Journal of Biological and Chemical Sciences 8(2): 717-726.

Jan, A. T., M. Azam, K. Siddiqui, A. Ali, I. Choi and Q. M. Haq (2015). "Heavy metals and human health: mechanistic insight into toxicity and counter defense system of antioxidants." International journal of molecular sciences 16(12): 29592-29630.

Jia, L., W. Wang, Y. Li and L. Yang (2010). "Heavy metals in soil and crops of an intensively farmed area: a case study in Yucheng City, Shandong Province, China." International Journal of Environmental Research and Public Health 7(2): 395-412.

Manea, D. N., A. A. Ienciu, R. Ştef, I. L. Şmuleac, I. I. Gergen and D. V. Nica (2020). "Health Risk Assessment of Dietary Heavy Metals Intake from Fruits and Vegetables Grown in Selected Old Mining Areas_A Case Study: The Banat Area of Southern Carpathians." International journal of environmental research and public health 17(14): 5172.

Mendoza, M. P., C. M. Llopis, J. Sánchez and L. R. Boix (2006). "Heavy metal content of agricultural soils in a Mediterranean semiarid area: the Segura River Valley (Alicante, Spain)." Spanish Journal of Agricultural Research(4): 363-372.

Muzeyen, A. (2019). "Determination Of The Levels Of Selected Essential And Nonessential Metals In Ketar River Water And The Onion (Allium Cepa L.), Irrigated Site Within 'Ketar Qote Bula' 'kebele (Golja) In The Case Of Tiyo Woreda Using Icp-Oes."

Onder, S., S. Dursun, S. Gezgin and A. Demirbas (2007). "Determination of Heavy Metal Pollution in Grass and Soil of City Centre Green Areas (Konya, Turkey)." Polish Journal of Environmental Studies 16(1).

Proshad, R., T. Kormoker, M. S. Islam and K. Chandra (2019). "Potential health risk of heavy metals via consumption of rice and vegetables grown in the industrial areas of Bangladesh." Human and ecological risk assessment: an international journal.

Samantaray, S. and P. Das (1997). "Accumulation of heavy metals(Cr, Ni and Fe) in mung bean(Vigna radiata cv. Local) grown on metalliferous minespoil." $\underline{\text { Fresenius }}$ Environmental Bulletin 6(11): 633-641. 
Sethy, S. K. and S. Ghosh (2013). "Effect of heavy metals on germination of seeds." Journal of natural science, biology, and medicine 4(2): 272.

Sharma, R. K. and M. Agrawal (2005). "Biological effects of heavy metals: an overview." Journal of environmental Biology 26(2): 301-313.

Smith, M. and F. K. Mohammed (2020). "Heavy metal intake and health risk implications from consumption of dried pulses in Trinidad and Tobago, WI." Food Additives \& Contaminants: Part B: 1-8.

Tegegne, W. A. (2015). "Assessment of some heavy metals concentration in selected cereals collected from local markets of Ambo City, Ethiopia." Journal of cereals and oilseeds 6(2): $8-13$.

World Health, O. (1996). "Permissible limits of heavy metals in soil and plants." Geneva, Switzerland. 